\title{
Nutrition, insulin-like growth factor-1 and retinopathy of prematurity
}

\section{Citation}

Hård, Anna-Lena, Lois E. Smith, and Ann Hellström. 2013. Nutrition, Insulin-Like Growth Factor-1 and Retinopathy of Prematurity. Seminars in Fetal and Neonatal Medicine 18, no. 3: 136-142. doi:10.1016/j.siny.2013.01.006.

\section{Published Version}

doi:10.1016/j.siny.2013.01.006

\section{Permanent link}

http://nrs.harvard.edu/urn-3:HUL.InstRepos:33776194

\section{Terms of Use}

This article was downloaded from Harvard University's DASH repository, and is made available under the terms and conditions applicable to Other Posted Material, as set forth at http:// nrs.harvard.edu/urn-3:HUL.InstRepos:dash.current.terms-of-use\#LAA

\section{Share Your Story}

The Harvard community has made this article openly available.

Please share how this access benefits you. Submit a story.

Accessibility 


\title{
Nutrition, insulin-like growth factor-1 and retinopathy of prematurity
}

\author{
Anna-Lena Hårda ${ }^{\mathrm{a}}$, Lois E. Smith ${ }^{\mathrm{b}}$, and Ann Hellström ${ }^{\mathrm{a},{ }^{*}}$ \\ aSection of Pediatric Ophthalmology, The Queen Silvia Children's Hospital, The Sahlgrenska \\ Academy at University of Gothenburg, S-416 85 Göteborg, Sweden \\ bDepartment of Ophthalmology, Children's Hospital Boston, Harvard Medical School, Boston, MA \\ 02115, USA
}

\section{SUMMARY}

Retinopathy of prematurity is a potentially blinding disease starting with impaired retinal vessel growth in the neonatal period. Weeks to months later, peripheral retinal hypoxia induces pathologic neo-vascularization that may lead to retinal detachment and blindness. Current treatment strategies target late stage disease and it would be advantageous if retinopathy of prematurity could be prevented. Poor general growth after very preterm birth is a universal problem associated with increased risk of retinopathy. Loss of the maternal-fetal interaction results not only in loss of nutrients but also of other factors provided in utero. The importance of nutrition and factors such as insulin-like growth factor- 1 and $\omega-3$ long chain fatty acids for proper retinal vascularization has been defined in animal studies. Increasing evidence of the applicability of these findings to human infants is accumulating. This review focuses on factors essential for neonatal growth and possible strategies to improve growth and prevent retinopathy.

\section{Keywords}

IGF-1; Nutrition; Omega-3; Retinopathy of prematurity

\section{Introduction}

For very preterm infants, the third trimester intrauterine milieu is replaced by an extrauterine environment for which they are poorly adjusted. At this stage, the central nervous system including the retina normally undergoes intense neurovascular growth and remodeling. In recent years, a strong association has been found between low serum insulin-like growth factor-1 (IGF-1) levels and poor weight gain during the first weeks of life and later retinopathy of prematurity (ROP). This review will explore the relationship between nutrition and these variables and possible therapeutic interventions to prevent ROP.

\footnotetext{
(C) 2013 Elsevier Ltd. All rights reserved.

Corresponding author. Tel.: +46768979196; fax: +46 31 848952. ann.hellstrom@medfak.gu.se (A. Hellström).

Conflict of interest statement

The application to prevent retinopathy of prematurity (ROP) by administering IGF-I is covered by patents and patent applications owned by Premacure AB, Uppsala, Sweden. Two of the authors (A.L.H. and A.H.) own shares in a company controlling Premacure $\mathrm{AB}$. The remaining author has nothing to declare.
} 


\section{Retinopathy of prematurity}

In the first phase of ROP there is retardation of retinal vessel growth and destruction of already formed vessels. ${ }^{1}$ The first sign of transition to the second phase of ROP is a demarcation line between vascularized and avascular retina. With increasing severity, this line becomes a ridge ${ }^{2}$ mainly composed of astrocyte precursors, possibly due to increased cell division or interrupted migration. ${ }^{3}$ Interestingly, hypoxic retinal ganglion cells secrete semaphorin $3 \mathrm{~A}$ which directs vessels away from the hypoxic area. ${ }^{4}$ In severe ROP, uncontrolled growth of abnormal blood vessels into the vitreous may lead to retinal detachment and blindness. Treatment with laser or off-label use of anti-VEGF (vascular endothelial growth factor) molecules targets late stage disease at risk for retinal detachment but is only partially effective in preventing blindness and not effective at increasing the number of patients with good visual acuity.

\section{Insulin like growth factor-1}

IGF-1, which is nutrition dependent, is essential for brain, muscle, bone and vascular growth and remodeling pre- and postnatally, mediated mainly through the IGF-1 receptor (IGF-1R) and regulated by at least six IGF-binding proteins (BPs). IGFBP-1 and IGFBP-3 appear to be the most important for fetal growth regulation. IGFBP-1 reduces the availability of IGF in serum and is associated with growth inhibition. ${ }^{5}$ However, some isoforms of IGFBP-1 with less affinity for IGF-1 are found in amniotic fluid and in serum of mid-gestational fetuses ${ }^{6}$ and have weaker growth-inhibiting or -promoting effects. ${ }^{5}$ IGFBP-3 binds IGF-1 with the acid labile subunit (ALS) in a ternary complex, prolonging half-life in the circulation. IGFBP-3 also has other IGF-1-independent protective actions on neurons and vessels. ${ }^{7,8}$

During the third trimester, IGF-1 serum levels normally increase two- to three-fold. ${ }^{9}$ Rare human IGF-1 gene defects cause both pre-and postnatal growth retardation, sensorineural deafness, microcephaly, intellectual deficit and later adiposity. ${ }^{10}$ The importance of IGF-1 for fetal and neonatal growth was shown in studies of IGF-1 knock-out mice that had a birth weight of $60 \%$ of normal and growth retardation after birth resulting in mice with $30 \%$ of normal weight after 8 weeks. ${ }^{11,12}$ Circulating IGF-1 is mainly produced by the liver, but IGF-1 is also secreted by almost all cells at some time during development. The roles of circulating versus locally secreted IGF-1 in somatic and brain growth are only partly known.

To address this problem, mouse models were developed that lack either liver-derived IGF-1 or IGF-1 produced in other organs. Without liver-derived IGF-1, but with normal expression in non-hepatic tissue, growth is not affected, suggesting that growth is mediated by autocrine/paracrine actions of IGF-1 as well as by non-liver sources of circulating IGF-1. ${ }^{13}$ However, when IGF-1 production in all organs except liver is blocked, endocrine IGF-1 then plays a very significant role in mouse growth. The authors propose that the actions of circulating and local IGF-1 are largely interchangeable, so that mice maintaining either appear normal. ${ }^{14}$

In mice, IGF-1 half-life in serum varies with binding. In the ternary complex (IGF-1/ IGFBP-3/ALS) IGF-1 half-life was 10-16 h; in the binary complex (IGFBP-3) it was 30-60 min and for free IGF-1 it was 10 min. ${ }^{15}$

New information about the roles and mechanisms of IGF-1 actions in the central nervous system has emerged. IGF-1 is expressed by all cells in the brain with the highest expression in the perinatal period. ${ }^{16}$ In addition, circulating IGF-1 enters the brain through the bloodbrain barrier, corresponding to the blood-retina barrier in the eye, through a transport mechanism mediated by astrocytes. Central nervous system IGF-1 entry is dependent on 
neuronal activity and directed to activated areas. ${ }^{17}$ In the developing brain, IGF-1 regulates glucose metabolism by mechanisms similar to those by which insulin controls peripheral glucose utilization. ${ }^{18}$ IGF-1 has profound effects on neuronal differentiation, growth and neuronal plasticity, thus influencing the cellular substrate for cognition. ${ }^{19}$

During pregnancy, the mother provides oxygen and essential nutrients to the fetus via the placenta, regulating fetal growth. IGF-1 levels in fetal serum (obtained at cordocentesis) increase with gestation and correlate with fetal size. ${ }^{9,20}$

\section{Normal fetal retinal vascularization}

Retinal vascularization starts at $\sim 12$ weeks of gestational age at the optic nerve. The area immediately anterior to the vasculature is densely populated with astrocyte precursors, which first appear in the optic nerve and retina at 8 weeks and extend to the retinal periphery at 28 weeks with reduced density by 32 weeks. ${ }^{21}$ Astrocytes are intimately associated with blood vessels during vascularization which initially occurs by vasculogenesis or blood vessel formation from vascular precursor cells which are restricted to the central two-thirds of the retina. ${ }^{22}$ The expansion of the vascular network then proceeds through angiogenesis or budding from formed vessels. Increased metabolic demands of the maturing retinal neurons anterior to the vascular front result in an expanding wave of 'physiological hypoxia', which induces expression of vascular endothelial growth factor (VEGF), which stimulates vascular growth, and the wave moves forward. ${ }^{23}$ In the retina, IGF-1 controls VEGF-mediated vascular growth ${ }^{24}$ by controlling the MAPK and Akt pathways, critical to endothelial cell proliferation and survival, possibly by mediating a switch from antiangiogenic to angiogenic VEGF isoforms. ${ }^{25}$ A minimum level of IGF-1 is needed for maximum VEGF signaling of Akt and MAPK. ${ }^{24}$

\section{Poor nutrition, low serum IGF-1 and poor postnatal weight gain and ROP}

\subsection{Animal studies}

Rodents have commonly been used for studies of oxygen-induced retinopathy (OIR) in the neonatal period. Mice and rats are born with almost avascular retinas (similar to a human of gestational age 5 months) and retinal vascularization mainly takes place during the first weeks of life. Exposure of mice or rat pups with incomplete retinal vascularization to high oxygen levels results in loss of retinal vessels followed by pathologic neo-vascularization after return to room air. ${ }^{26}$

In 1956 the Swede Bo Hellström reported that poor nutrition in mouse pups resulted in poor weight gain and also in slightly reduced growth of retinal vessels. Exposure to $98-100 \%$ oxygen almost completely stopped vessel outgrowth irrespective of the state of nutrition. Poor neonatal growth followed by later catch-up growth, which is common in preterm infants, appeared to be associated with increased risk of retinopathy in mice, as had been noted in 1953 by Lubchenco in infants. ${ }^{27}$ Poorly fed newborn mice exposed to 10 days of oxygen, then returned to room air for 10 days, developed pathological neovascularization in only two out of 12 pups, whereas 12 out of 12 pups that were undernourished during oxygen exposure but received a normal diet thereafter had extra-retinal neovascularization. ${ }^{28}$

Interestingly, in a rat OIR model, starvation affected the outgrowth of the vasculature more than growth of the retina, resulting in a smaller ratio of vascularized-to-total retina. Underfed pups also developed more neovascularization than well-fed pups. A smaller area of normal vascularization was associated with higher incidence and severity of abnormal neovascularization. This study agrees with other reports that the size of the peripheral 
avascular zone determines the incidence of, and severity of, neo-vascularization in rats exposed to variable oxygen. ${ }^{29,30}$

Acidosis in the neonatal period results in acidosis-induced retinopathy (AIR), similar to OIR. AIR also results in more neo-vascularization in underfed versus normally fed rat pups. ${ }^{31}$ Recently, OIR in mice with poor weight gain showed a delayed onset and prolonged course of neovascularization and VEGF expression. ${ }^{32}$

IGF-1 knock-out mice lack IGF-1 both before and after birth and have impaired retinal vessel growth. ${ }^{24}$ Vanhaesebrouck et al. ${ }^{33}$ showed that postnatal undernutrition in wild type OIR mice was associated with reduced weight gain, low serum IGF-1 and more severe neovascularization compared with normally fed peers. Importantly, when underfed mice were treated with recombinant human (rh) IGF-1, growth and maturation increased and OIR decreased. ${ }^{33}$ This agrees with the finding that IGF-1 ameliorates growth in states of undernutrition by improving food utilization. ${ }^{34}$

\subsection{Clinical studies}

For the newborn infant, normal weight gain after birth indicates health. Unfortunately, postnatal growth retardation is a major problem in very preterm infants (normalized for gestational age and sex) resulting in lower-weight standard deviation score (SDS) at discharge versus SDS at birth. ${ }^{35}$

The association between poor neonatal growth and severe ROP has been found in several studies. ${ }^{36-39}$ In the Swedish national EXPRESS study of infants with gestational age <27 weeks, weight SDS at 36 weeks of postmenstrual age was highly negatively associated with proliferative $\mathrm{ROP}^{40}$ (Fig. 1 $^{41,42}$ ).

Serum concentrations of IGF-1 fall sharply after very preterm birth. In two studies of 136 infants with gestational age between 24 and 32 weeks at birth, the decreased level and duration of low IGF-1 values during 30-33 weeks of postmenstrual age were correlated with ROP severity (Fig. 2). ${ }^{41,42}$

\subsection{The screening algorithm 'WINROP'}

Current screening for ROP is based on gestational age and birth weight. Since the vast majority ( $\sim 90 \%$ ) of infants who undergo repeated painful examinations for ROP require no treatment, better selection of infants at risk is urgently needed. Since weight gain and serum IGF-1 levels are associated with later ROP we developed the ROP prediction algorithm Weight IGF-1 Neonatal ROP (WINROP). WINROP was constructed to detect deviations between the rate of weight and serum IGF-1 gain of 13 infants with proliferative ROP versus 38 infants with no or mild ROP using online statistical surveillance (www.winrop.com). ${ }^{43}$

An alarm is shown when the accumulated deviation reaches a certain level before a PMA of 33 weeks. Since serial blood tests are needed for IGF-1 analyses and weight gain reflects IGF-1 levels, we tested whether WINROP could predict ROP using weight gain alone. Infants with hydrocephalus were excluded since their weights partly reflected accumulation of fluid in the head. In this retrospective study of 353 infants with weekly weights, but no IGF-1 values, WINROP correctly identified all infants with later proliferative ROP with sensitivity of $100 \%$. Specificity was $84.5 \%$. Based on weights only, WINROP has now been validated in $>10000$ infants in different parts of the world with high sensitivity and somewhat lower specificity. ${ }^{44-48}$ WINROP has provided new information concerning the importance of early postnatal weight gain, which gives us a better understanding of ROP pathogenesis and allows modification of traditional screening for both low and 


\section{Why is it so hard to achieve good neonatal growth in very preterm infants?}

Very preterm infants frequently become growth-restricted after birth and nutritional strategies to improve growth have not been optimized. The recommended amounts of nutrients are seldom given. In addition, the optimal growth velocity is not known and currently recommended rates of growth appear to be too low. In the US multicenter Extremely Low Gestational Age Newborn (ELGAN) study of 1506 infants born between 23 and $276 / 7$ gestational weeks, less nutrition was provided than was recommended. Although current growth velocity goals were reached, $75 \%$ of the infants had a weight below the 10th centile at 28 days compared to $18 \%$ at birth (Fig. 3) ${ }^{49}$ Ehrenkranz et al.${ }^{50}$ followed the weight gain of 1660 infants with birth weight of 501-1500 g. Most of the infants born at gestational age 24-29 weeks had not achieved the median birth weight of the reference fetuses of the same PMA at discharge. Infants with major morbidities grew even more slowly than healthier infants. ${ }^{50}$ The etiology of the postnatal growth restriction in pre-term infants is multifactorial and only partly known. The following contributing factors will be discussed:

- increased frequency of intrauterine growth restriction

- increased metabolic rate

- insufficient nutrition

- low serum IGF-1 concentrations

- oxygen treatment.

\subsection{Intrauterine growth restriction}

Intrauterine growth restriction increases the risk of preterm birth as demonstrated in the ELGAN study where $18 \%$ of infants were growth-restricted (weight $<10$ th centile) already at birth. ${ }^{49}$

\subsection{Increased metabolic rate}

The postnatal metabolic rate of the preterm infant is higher than that of a fetus in utero surrounded by its mother with a metabolic rate similar to hers. In mammals, small size is associated with increased metabolism presumably to compensate for heat loss through a relatively larger surface area. Preterm infants undergo a prolonged adaptation to an extrauterine metabolism appropriate for size resulting in increased calorie demands compared to those of a fetus of the same age. ${ }^{51}$ Energy requirements are also higher in infants with diseases associated with preterm birth such as chronic lung disease. ${ }^{52}$

\subsection{Insufficient nutrition}

Premature birth results in loss of the placenta, the amnion and amniotic fluid which is rich in nutrients and growth factors including IGF-1. Amniotic fluid is normally swallowed by the fetus and contributes to fetal growth. ${ }^{53,54}$ After very preterm birth, immaturity of the gastrointestinal tract including the liver and pancreas and other organs prevents sufficient enteral feeding which is important for gut maturation. ${ }^{55}$ Total parenteral nutrition contains some basic nutrients but lacks other factors, many probably unknown, which are normally provided in utero. 


\subsection{Low serum IGF-1 concentrations}

IGF-1 serum levels fall rapidly after preterm birth, due to loss of the maternal-fetal interaction. Since liver IGF-1 synthesis is mainly regulated by energy and amino acid availability, low serum levels are a natural consequence of the poor initial nutrient intake of most very preterm infants. However, other factors may contribute to low circulating IGF-1. Since neuronal activity in the brain has been found to result in the passage of IGF-1 from the circulation to the brain ${ }^{17}$ and preterm birth exposes the infant to light and visual stimulation as well as other sensory stimulation earlier than normally, one might speculate that the passage of IGF-1 from the circulation into the brain is increased compared to intrauterine.

\section{Lack of essential nutrients that might influence ROP risk}

\section{1. $\omega-3$ polyunsaturated fatty acids}

During the third trimester, a massive transfer of long chain polyunsaturated fatty acids (LCPUFAs) from the mother to the fetus takes place. Docosahexaenoic acid (DHA), an $\omega-3-$ LCPUFA derived from cold water algae and oily fish, is the predominant fatty acid of membrane phospholipids in the brain gray matter and the retina, and the only $\omega-3$-LCPUFA present in significant amounts in the brain. In the third trimester, there is a massive placental transfer of DHA from the mother to the fetus during the time of rapid formation of synapses and dendritic spines and development of retinal photoreceptor cells. ${ }^{56}$ The lipid bilayers of rod photoreceptors are made up of phosphoglycerides with $>50 \%$ DHA. Absolute accretion of DHA in the brain is greater before than after term birth. ${ }^{57}$ Since the capacity to synthesize DHA is very limited in humans, especially in infants, it needs to be provided in the diet. ${ }^{58,59}$ DHA is not merely a structural component of cell membranes but is essential for proper function of membranes. Dietary DHA is needed for optimal functional maturation of the retina and visual cortex and prevents photoreceptor apoptosis during early development (in vitro) and during oxidative stress. ${ }^{60,61}$ DHA is a major component at the synaptic site, modulating the uptake and release of neurotransmitters.

At preterm birth, DHA provided via the placenta is no longer available and the infant's reserves are insufficient. ${ }^{57}$ In a study of infants with gestational age $24-296 / 7$ weeks, the blood DHA level at birth was $6.9 \pm 0.2 \mathrm{~mol} \%$ with little variation between gestational ages and similar to those found in term infants. Parenteral lipid infusion with soybean-oil based Intralipid (Fresenius Kabi, Bad Homburg, Germany) was started day 2 and most infants still received some parenteral nutrition at 2 weeks of age. The meanDHA level fell by $\sim 40 \%$ at week 1 and then remained low for at least 4 weeks postnatally (Fig. 4). Later full enteral feeding with breast milk or DHA-supplemented formula could not overcome the blood DHA deficit after birth. ${ }^{62}$

In mice with OIR (75\% oxygen days P7-12), the pups of dams fed a diet rich in $\omega-3$ LCPUFAs compared to those fed a diet rich in $\omega$-6-LCPUFAs had the same degree of vascular development at P6 and vaso-obliteration at P12, but had less avascular retinal area from P13 to P17 and less pathologic neovascularization at P17, indicating that $\omega$-3-PUFA increased revascularization of avascular retina, suppressing neovascularization. ${ }^{63}$

In the retina, $\omega-6$-PUFA increases activated microglial production of tumour necrosis factor$\alpha$, whereas this production is reduced by elevated $\omega-3$ possibly due to the protective effects of the $\omega-3$ PUFA-derived resolvins and neuroprotectins. ${ }^{63} \omega-3$-PUFA also directly suppresses neovascularization through the anti-angiogenic effect of the 5-lipoxygenasederived DHA metabolite 4-hydroxy-DHA, mediated through the peroxisome proliferatoractivated receptor (PPAR)- $\gamma$ receptor. Administration of $\omega$-3PUFAs exclusively during the neovascular stage, at P14-17 strongly decreased the neovascular activity of the retina via 
PPAR- $\gamma$-dependent reduction of inflammatory mediators and attenuation of endothelial cell activation. ${ }^{64,65}$

In a recent Polish study, infants with birth weight $<1250 \mathrm{~g}$ born before gestational age 32 weeks, needing total parenteral nutrition from day 1 , received a lipid emulsion consisting of equal parts of 20\% Clinoleic (soy bean and olive oil) (Baxter SA, Norfolk UK) and 10\% Omegaven [with fish oil (DHA)] (Fresenius Kabi AG). A historic control group received Clinoleic only. The frequency of retinopathy in the two groups was similar, 32.5 versus $36.3 \%$. However, regression of disease was more frequent in the Omegaven-treated group and fewer needed laser treatment. ${ }^{66}$

Twenty years ago, Martinez suggested that parenteral lipids and milk formulas should be enriched with DHA to provide $0.5-1.0 \%$ of total fatty acids, with preterm infants especially sensitive to the effect of dietary fatty acid imbalances.${ }^{67}$ Nowadays formulas for enteral use in preterm infants are commonly DHA-supplemented. However, for parenteral use during the first weeks of life, Intralipid is the most used lipid source, resulting in severe DHA deficiency during the first postnatal week. ${ }^{62}$ The newer emulsion Clinoleic contains even less DHA than Intralipid $(0.23 \%$ versus $0.34 \%){ }^{68}$

\section{Parenteral nutrition, breast milk and formula}

Normally, loss of the placenta and amnion is immediately followed by ingestion of mother's colostrum and milk which provides unique nutrients including DHA ${ }^{69}$ and hormones and growth factors including IGF-1. ${ }^{70}$ Colostrum contains very high concentrations of IGF-1 which decline during the first days of life. ${ }^{71}$ Very preterm infants often require more nutrients than can be provided by enteral feeding during the first postnatal weeks and parenteral nutrition in the neonatal period is frequently performed. Duration of parenteral nutrition has been recognized as a risk factor for ROP. ${ }^{72}$ Contradictory results have been reported regarding breast-feeding and ROP risk possibly partly due to differences in study design. Protective effects have been found in some studies ${ }^{73-76}$ whereas other authors reported no association between human milk feedings and ROP. ${ }^{77}$ Current recommendations of mother's milk as the best source of nutrition for preterm infants precludes randomized controlled trials comparing breast milk and formulas.

\subsection{Inositol}

Inositol insufficiency is associated with ROP. ${ }^{78}$ This carbohydrate is present in high concentrations in breast milk $\mathrm{k}^{79}$ and lower serum levels in preterm infants are found after prolonged parenteral nutrition. ${ }^{80}$ Administration of inositol to infants with respiratory distress syndrome, who received parenteral nutrition during the first week of life, is associated with decreased incidence of ROP. ${ }^{81}$

\subsection{Vitamin $\mathrm{E}$}

Preterm infants have an immature antioxidant system and are susceptible to oxidative stress. Vitamin E, a free radical scavenger, was tested to prevent ROP. ${ }^{82}$ High doses of vitamin E tended to decrease ROP and blindness but to increase the risk of sepsis. ${ }^{83}$ However, current enteral and parenteral nutrition options result in less vitamin E provided than recommended for very low birth weight infants. ${ }^{73}$

\section{Oxygen treatment}

Hyperoxia is clearly a risk factor for ROP. Fluctuating oxygen levels appear to be as harmful or more than constant hyperoxia. ${ }^{84}$ Interestingly, rat pups exposed to hyperoxia 
interrupted by clustered episodes of hypoxia not only developed severe OIR but also low body weight and low systemic IGF-1 levels. ${ }^{85}$

\section{Possible therapeutic interventions to prevent ROP}

\subsection{Increased and optimized nutrition}

Inappropriate fear of early amino acid administration stemming from a time when the first generation of amino acid solutions induced adverse reactions has resulted in early protein deficits in preterm infants. High doses of amino acids early are effective and safe. Early aggressive nutrition with amino acids and lipids is associated with higher levels of IGF-1 and IGFBP-3 at 40 weeks of PMA which are negatively associated with ROP. ${ }^{86}$ However, in a study of infants with gestational age $<31$ weeks, nutrient intake during the initial postnatal phase of growth retardation did not affect either serum IGF-1 or growth, but in the subsequent phase of catch-up growth starting 30 weeks PMA, both serum IGF-1 and circulating IGF-1 were modified by nutrient intake. During the whole period, serum IGF-1 was associated with growth. The most immature infants experienced a more pronounced decrease in weight SDS and the growth retardation phase was prolonged although this could not be explained by lower accumulated nutritional intake. ${ }^{87}$ Thus, the most immature infants appear to have impaired ability to utilize the nutrients provided. After increased nutrition regimens, Kaempf et al.$^{88}$ noted an increase in hyperglycaemia and insulin use, which was associated with more proliferative ROP (4\% in 2001 versus 9\% in 2009). Others have confirmed the association between hyperglycemia and insulin use and ROP. ${ }^{89-91}$ Not only more nutrition, but also more appropriate composition of nutrient solutions with factors essential for normal development such as DHA, vitamin E and inositol might help prevent ROP.

\subsection{Supplementation with IGF-1}

Since low serum IGF-1 in very preterm infants is strongly associated with poor weight gain and ROP and other morbidities, and since supplementation with IGF-1 in experimental studies improves growth and prevents ROP, ${ }^{72}$ supplementation with IGF-1 might be used to improve postnatal growth and outcome. At present, a phase II study known as Insulin-Like Growth Factor 1 (IGF-1) in the prevention of Complications of Preterm Birth (ClinicalTrials. gov Id:NCT01096784) is recruiting patients in Sweden. ${ }^{92}$

\section{Conclusion}

In order to achieve better early growth and prevention of ROP, possible preventive measures that need further evaluation include better nutrition, supplementation with IGF-1 and nutritive factors found to be missing in very preterm infants such as DHA, vitamin $\mathrm{E}$ and inositol.

\section{Acknowledgments}

Funding sources

None.

\section{References}

1. Garner A, Ashton N. Vaso-obliteration and retrolental fibroplasia. Proc R Soc Med. 1971; 64:774-7. [PubMed: 5109153]

2. International Committee for the Classification of Retinopathy of Prematurity. The international classification of retinopathy of prematurity revisited. Arch Ophthalmol. 2005; 123:991-9. [PubMed: 16009843] 
3. Sun Y, Dalal R, Gariano RF. Cellular composition of the ridge in retinopathy of prematurity. Arch Ophthalmol. 2010; 128:638-41. [PubMed: 20457991]

4. Joyal JS, Sitaras N, Binet F, et al. Ischemic neurons prevent vascular regeneration of neural tissue by secreting semaphorin 3A. Blood. 2011; 117:6024-35. [PubMed: 21355092]

5. Kajantie E, Dunkel L, Rutanen EM, et al. IGF-I, IGF binding protein (IGFBP)-3, phosphoisoforms of IGFBP-1, and postnatal growth in very low birth weight infants. J Clin Endocrinol Metab. 2002; 87:2171-9. [PubMed: 11994360]

6. Jones JI, D'Ercole AJ, Camacho-Hubner C, Clemmons DR. Phosphorylation of insulin-like growth factor (IGF)-binding protein 1 in cell culture and in vivo: effects on affinity for IGF-I. Proc Natl Acad Sci U S A. 1991; 88:7481-5. [PubMed: 1715565]

7. Kielczewski JL, Hu P, Shaw LC, et al. Novel protective properties of IGFBP-3 result in enhanced pericyte ensheathment, reduced microglial activation, increased microglial apoptosis, and neuronal protection after ischemic retinal injury. Am J Pathol. 2011; 178:1517-28. [PubMed: 21435441]

8. Kielczewski JL, Jarajapu YP, McFarland EL, et al. Insulin-like growth factor binding protein-3 mediates vascular repair by enhancing nitric oxide generation. Circ Res. 2009; 105:897-905. [PubMed: 19762684]

9. Lassarre C, Hardouin S, Daffos F, Forestier F, Frankenne F, Binoux M. Serum insulin-like growth factors and insulin-like growth factor binding proteins in the human fetus. Relationships with growth in normal subjects and in subjects with intrauterine growth retardation. Pediatr Res. 1991; 29:219-25. [PubMed: 1709729]

10. Netchine I, Azzi S, Le Bouc Y, Savage MO. IGF1 molecular anomalies demonstrate its critical role in fetal, postnatal growth and brain development. Best Pract Res Clin Endocrinol Metab. 2011; 25:181-90. [PubMed: 21396584]

11. Liu JP, Baker J, Perkins AS, Robertson EJ, Efstratiadis A. Mice carrying null mutations of the genes encoding insulin-like growth factor I (Igf-1) and type 1 IGF receptor (Igf1r). Cell. 1993; 75:59-72. [PubMed: 8402901]

12. Baker J, Liu JP, Robertson EJ, Efstratiadis A. Role of insulin-like growth factors in embryonic and postnatal growth. Cell. 1993; 75:73-82. [PubMed: 8402902]

13. Sjogren K, Liu JL, Blad K, et al. Liver-derived insulin-like growth factor I (IGF-I) is the principal source of IGF-I in blood but is not required for postnatal body growth in mice. Proc Natl Acad Sci U S A. 1999; 96:7088-92. [PubMed: 10359843]

14. Stratikopoulos E, Szabolcs M, Dragatsis I, Klinakis A, Efstratiadis A. The hormonal action of IGF1 in postnatal mouse growth. Proc Natl Acad Sci U S A. 2008; 105:19378-83. [PubMed: 19033454]

15. Yakar S, Rosen CJ, Beamer WG, et al. Circulating levels of IGF-1 directly regulate bone growth and density. J Clin Invest. 2002; 110:771-81. [PubMed: 12235108]

16. Bach MA, Shen-Orr Z, Lowe WL Jr, Roberts CT Jr, LeRoith D. Insulin-like growth factor I mRNA levels are developmentally regulated in specific regions of the rat brain. Brain Res Mol Brain Res. 1991; 10:43-8. [PubMed: 1647481]

17. Nishijima T, Piriz J, Duflot S, et al. Neuronal activity drives localized blood- brain-barrier transport of serum insulin-like growth factor-I into the CNS. Neuron. 2010; 67:834-46. [PubMed: 20826314]

18. Cheng CM, Reinhardt RR, Lee WH, Joncas G, Patel SC, Bondy CA. Insulin-like growth factor 1 regulates developing brain glucose metabolism. Proc Natl Acad Sci U S A. 2000; 97:10236-41. [PubMed: 10954733]

19. Torres-Aleman I. Toward a comprehensive neurobiology of IGF-I. Dev Neurobiol. 2010; 70:38496. [PubMed: 20186710]

20. Langford K, Nicolaides K, Miell JP. Maternal and fetal insulin-like growth factors and their binding proteins in the second and third trimesters of human pregnancy. Hum Reprod. 1998; 13:1389-93. [PubMed: 9647578]

21. Chu Y, Hughes S, Chan-Ling T. Differentiation and migration of astrocyte precursor cells and astrocytes in human fetal retina: relevance to optic nerve coloboma. FASEB J. 2001; 15:2013-5. [PubMed: 11511521] 
22. Chan-Ling T, McLeod DS, Hughes S, et al. Astrocyte-endothelial cell relationships during human retinal vascular development. Invest Ophthalmol Vis Sci. 2004; 45:2020-32. [PubMed: 15161871]

23. Stone J, Itin A, Alon T, et al. Development of retinal vasculature is mediated by hypoxia-induced vascular endothelial growth factor (VEGF) expression by neuroglia. J Neurosci. 1995; 15(7 Pt 1): 4738-47. [PubMed: 7623107]

24. Hellström A, Perruzzi C, Ju M, et al. Low IGF-I suppresses VEGF-survival signaling in retinal endothelial cells: direct correlation with clinical retinopathy of prematurity. Proc Natl Acad Sci U S A. 2001; 98:5804-8. [PubMed: 11331770]

25. Nowak DG, Amin EM, Rennel ES, et al. Regulation of vascular endothelial growth factor (VEGF) splicing from pro-angiogenic to anti-angiogenic isoforms: a novel therapeutic strategy for angiogenesis. J Biol Chem. 2010; 285:5532-40. [PubMed: 19906640]

26. Smith LE, Wesolowski E, McLellan A, et al. Oxygen-induced retinopathy in the mouse. Invest Ophthalmol Vis Sci. 1994; 35:101-11. [PubMed: 7507904]

27. Lubchenco LO, Boyd E, Dressler MS. Growth of prematurely born infants with and without retrolental fibroplasia. Am J Dis Child. 1953; 86:466-8.

28. Hellström BE. Experimental approach to the pathogenesis of retrolental fibroplasia. V. The influence of the state of nutrition on oxygen-induced changes in the mouse eye. Acta Paediatr. 1956; 45:43-57. [PubMed: 13313128]

29. Reynaud X, Dorey CK. Extraretinal neovascularization induced by hypoxic episodes in the neonatal rat. Invest Ophthalmol Vis Sci. 1994; 35:3169-77. [PubMed: 8045712]

30. Penn JS, Tolman BL, Lowery LA. Variable oxygen exposure causes preretinal neovascularization in the newborn rat. Invest Ophthalmol Vis Sci. 1993; 34:576-85. [PubMed: 8449677]

31. Zhang S, Leske DA, Lanier WL, Holmes JM. Postnatal growth retardation exacerbates acidosisinduced retinopathy in the neonatal rat. Curr Eye Res. 2001; 22:133-9. [PubMed: 11402390]

32. Stahl A, Chen J, Sapieha P, et al. Postnatal weight gain modifies severity and functional outcome of oxygen-induced proliferative retinopathy. Am J Pathol. 2010; 177:2715-23. [PubMed: 21056995]

33. Vanhaesebrouck S, Daniels H, Moons L, Vanhole C, Carmeliet P, De Zegher F. Oxygen-induced retinopathy in mice: amplification by neonatal IGF-I deficit and attenuation by IGF-I administration. Pediatr Res. 2009; 65:307-10. [PubMed: 19092722]

34. Fryklund, L.; Gluckman, P.; Skottner, A. Treatment of catabolic states using authentic IGF-I and hypocaloric amount of nutrients. United States Patent Number. 6,034,059. published 7 March 2000

35. Cooke RJ, Ainsworth SB, Fenton AC. Postnatal growth retardation: a universal problem in preterm infants. Arch Dis Child Fetal Neonatal Ed. 2004; 89:F428-30. [PubMed: 15321963]

36. Hall JG, Freedman SF, Kylstra JA. Clinical course and systemic correlates of retinopathy of prematurity in quintuplets. Am J Ophthalmol. 1995; 119:658-60. [PubMed: 7733197]

37. Wallace DK, Kylstra JA, Phillips SJ, Hall JG. Poor postnatal weight gain: a risk factor for severe retinopathy of prematurity. J AAPOS. 2000; 4:343-7. [PubMed: 11124668]

38. Allegaert K, Vanhole C, Casteels I, et al. Perinatal growth characteristics and associated risk of developing threshold retinopathy of prematurity. J AAPOS. 2003; 7:34-7. [PubMed: 12690367]

39. Fortes Filho JB, Bonomo PP, Maia M, Procianoy RS. Weight gain measured at 6 weeks after birth as a predictor for severe retinopathy of prematurity: study with 317 very low birth weight preterm babies. Graefes Arch Clin Exp Ophthalmol. 2009; 247:831-6. [PubMed: 19052770]

40. EXPRESS Group. Incidence of and risk factors for neonatal morbidity after active perinatal care: extremely preterm infants study in Sweden (EXPRESS). Acta Paediatr. 2010; 99:978-92. [PubMed: 20456261]

41. Hellström A, Engström E, Hård AL, et al. Postnatal serum insulin-like growth factor I deficiency is associated with retinopathy of prematurity and other complications of premature birth. Pediatrics. 2003; 112:1016-20. [PubMed: 14595040]

42. Löfqvist C, Hansen-Pupp I, Andersson E, et al. Validation of a new retinopathy of prematurity screening method monitoring longitudinal postnatal weight and insulinlike growth factor I. Arch Ophthalmol. 2009; 127:622-7. [PubMed: 19433710] 
43. Löfqvist C, Andersson E, Sigurdsson J, et al. Longitudinal postnatal weight and insulin-like growth factor I measurements in the prediction of retinopathy of prematurity. Arch Ophthalmol. 2006; 124:1711-8. [PubMed: 17159030]

44. Wu C, Vanderveen DK, Hellström A, Löfqvist C, Smith LE. Longitudinal postnatal weight measurements for the prediction of retinopathy of prematurity. Arch Ophthalmol. 2010; 128:4437. [PubMed: 20385939]

45. Hard AL, Löfqvist C, Fortes Filho JB, Procianoy RS, Smith L, Hellström A. Predicting proliferative retinopathy in a Brazilian population of preterm infants with the screening algorithm WINROP. Arch Ophthalmol. 2010; 128:1432-6. [PubMed: 21060045]

46. Fluckiger S, Bucher HU, Hellström A, Löfqvist C, Sturm V, Arri SJ. The early postnatal weight gain as a predictor of retinopathy of prematurity. Klin Monbl Augenheilkd. 2011; 228:306-10. [PubMed: 21484635]

47. Wu C, Löfqvist C, Smith LE, Vanderveen DK, Hellström A. Importance of early postnatal weight gain for normal retinal angiogenesis in very preterm infants: a multicenter study analyzing weight velocity deviations for the prediction of retinopathy of prematurity. Arch Ophthalmol. 2012

48. Zepeda-Romero LC, Hård AL, Gomez-Ruiz LM, et al. Prediction of retinopathy of prematurity using the screening algorithm WINROP in a Mexican population of preterm infants. Arch Ophthalmol. 2012; 130:720-3. [PubMed: 22801831]

49. Martin CR, Brown YF, Ehrenkranz RA, et al. Nutritional practices and growth velocity in the first month of life in extremely premature infants. Pediatrics. 2009; 124:649-57. [PubMed: 19651583]

50. Ehrenkranz RA, Younes N, Lemons JA, et al. Longitudinal growth of hospitalized very low birth weight infants. Pediatrics. 1999; 104(2 Pt 1):280-9. [PubMed: 10429008]

51. Singer D, Muhlfeld C. Perinatal adaptation in mammals: the impact of metabolic rate. Comp Biochem Physiol A Mol Integr Physiol. 2007; 148:780-4. [PubMed: 17561425]

52. Kurzner SI, Garg M, Bautista DB, et al. Growth failure in infants with bron-chopulmonary dysplasia: nutrition and elevated resting metabolic expenditure. Pediatrics. 1988; 81:379-84. [PubMed: 3344181]

53. Underwood MA, Gilbert WM, Sherman MP. Amniotic fluid: not just fetal urine anymore. J Perinatol. 2005; 25:341-8. [PubMed: 15861199]

54. Burjonrappa SC, Crete E, Bouchard S. The role of amniotic fluid in influencing neonatal birth weight. J Perinatol. 2010; 30:27-9. [PubMed: 19626029]

55. Neu J. Gastrointestinal development and meeting the nutritional needs of premature infants. Am J Clin Nutr. 2007; 85:629S-34S. [PubMed: 17284768]

56. Martinez M, Ballabriga A. A chemical study on the development of the human forebrain and cerebellum during the brain 'growth spurt' period. I. Gangliosides and plasmalogens. Brain Res. 1978; 159:351-62. [PubMed: 728805]

57. Clandinin MT, Chappell JE, Leong S, Heim T, Swyer PR, Chance GW. Intrauterine fatty acid accretion rates in human brain: implications for fatty acid requirements. Early Hum Dev. 1980; 4:121-9. [PubMed: 7408742]

58. Brenna JT. Efficiency of conversion of alphalinolenic acid to long chain n-3 fatty acids in man. Curr Opin Clin Nutr Metab Care. 2002; 5:127-32. [PubMed: 11844977]

59. Salem N Jr, Wegher B, Mena P, Uauy R. Arachidonic and docosahexaenoic acids are biosynthesized from their 18-carbon precursors in human infants. Proc Natl Acad Sci U S A. 1996; 93:49-54. [PubMed: 8552667]

60. Uauy R, Dangour AD. Nutrition in brain development and aging: role of essential fatty acids. Nutr Rev. 2006; 64(5 Pt 2):S24-33. discussion S72-91. [PubMed: 16770950]

61. German OL, Insua MF, Gentili C, Rotstein NP, Politi LE. Docosahexaenoic acid prevents apoptosis of retina photoreceptors by activating the ERK/MAPK pathway. J Neurochem. 2006; 98:1507-20. [PubMed: 16923163]

62. Martin CR, Dasilva DA, Cluette-Brown JE, et al. Decreased postnatal docosa-hexaenoic and arachidonic acid blood levels in premature infants are associated with neonatal morbidities. $\mathrm{J}$ Pediatr. 2011; 159:743-9. e1-2. [PubMed: 21658712] 
63. Connor KM, SanGiovanni JP, Löfqvist C, et al. Increased dietary intake of omega-3polyunsaturated fatty acids reduces pathological retinal angiogenesis. Nat Med. 2007; 13:868-73. [PubMed: 17589522]

64. Sapieha P, Stahl A, Chen J, et al. 5-Lipoxygenase metabolite 4-HDHA is a mediator of the antiangiogenic effect of $\omega-3$ polyunsaturated fatty acids. Sci Transl Med. 2011; 3:69ra12.

65. Stahl A, Sapieha P, Connor KM, et al. Short communication: PPAR gamma mediates a direct antiangiogenic effect of omega 3-PUFAs in proliferative retinopathy. Circ Res. 2010; 107:495500. [PubMed: 20634487]

66. Pawlik D, Lauterbach R, Turyk E. Fish-oil fat emulsion supplementation may reduce the risk of severe retinopathy in VLBW infants. Pediatrics. 2011; 127:223-8. [PubMed: 21199856]

67. Martinez M. Tissue levels of polyunsaturated fatty acids during early human development. J Pediatr. 1992; 120(4 Pt 2):S129-38. [PubMed: 1532827]

68. Gobel Y, Koletzko B, Bohles HJ, et al. Parenteral fat emulsions based on olive and soybean oils: a randomized clinical trial in preterm infants. J Pediatr Gastroenterol Nutr. 2003; 37:161-7. [PubMed: 12883303]

69. Koletzko B, Rodriguez-Palmero M. Polyunsaturated fatty acids in human milk and their role in early infant development. J Mammary Gland Biol Neoplasia. 1999; 4:269-84. [PubMed: 10527469]

70. Buts JP. Bioactive factors in milk. Arch Pediatr. 1998; 5:298-306. [PubMed: 10328000]

71. Baxter RC, Zaltsman Z, Turtle JR. Immunoreactive somatomedin-C/insulin-like growth factor I and its binding protein in human milk. J Clin Endocrinol Metab. 1984; 58:955-9. [PubMed: 6202711]

72. Vanhaesebrouck S, Vanhole C, de Zegher F, Allegaert K. Influence of duration of parenteral nutrition on retinopathy of prematurity. Arch Dis Child Fetal Neonatal Ed. 2008; 93:F170. [PubMed: 18296578]

73. Porcelli PJ, Weaver RG Jr. The influence of early postnatal nutrition on retinopathy of prematurity in extremely low birth weight infants. Early Hum Dev. 2010; 86:391-6. [PubMed: 20561759]

74. Okamoto T, Shirai M, Kokubo M, et al. Human milk reduces the risk of retinal detachment in extremely low-birthweight infants. Pediatr Int. 2007; 49:894-7. [PubMed: 18045292]

75. Maayan-Metzger A, Avivi S, Schushan-Eisen I, Kuint J. Human milk versus formula feeding among preterm infants: short-term outcomes. Am J Perinatol. 2012; 29:121-6. [PubMed: 22094917]

76. Hylander MA, Strobino DM, Pezzullo JC, Dhanireddy R. Association of human milk feedings with a reduction in retinopathy of prematurity among very low birthweight infants. J Perinatol. 2001; 21:356-62. [PubMed: 11593368]

77. Heller CD, O'Shea M, Yao Q, et al. Human milk intake and retinopathy of prematurity in extremely low birth weight infants. Pediatrics. 2007; 120:1-9. [PubMed: 17606555]

78. Friedman CA, McVey J, Borne MJ, et al. Relationship between serum inositol concentration and development of retinopathy of prematurity: a prospective study. J Pediatr Ophthalmol Strabismus. 2000; 37:79-86. [PubMed: 10779265]

79. Cavalli C, Teng C, Battaglia FC, Bevilacqua G. Free sugar and sugar alcohol concentrations in human breast milk. J Pediatr Gastroenterol Nutr. 2006; 42:215-21. [PubMed: 16456418]

80. Carver JD, Stromquist CI, Benford VJ, Minervini G, Benford SA, Barness LA. Postnatal inositol levels in preterm infants. J Perinatol. 1997; 17:389-92. [PubMed: 9373845]

81. Howlett A, Ohlsson A, Plakkal N. Inositol for respiratory distress syndrome in preterm infants. Cochrane Database Syst Rev. 2012; 3:CD000366. [PubMed: 22419275]

82. Owens WC, Owens EU. Retrolental fibroplasia in premature infants; studies on the prophylaxis of the disease; the use of alpha tocopheryl acetate. Am J Ophthalmol. 1949; 32:1631-7. [PubMed: 15399166]

83. Brion LP, Bell EF, Raghuveer TS. Vitamin E supplementation for prevention of morbidity and mortality in preterm infants. Cochrane Database Syst Rev. 2003; 4:CD003665. [PubMed: 14583988]

84. York JR, Landers S, Kirby RS, Arbogast PG, Penn JS. Arterial oxygen fluctuation and retinopathy of prematurity in very-low-birth-weight infants. J Perinatol. 2004; 24:82-7. [PubMed: 14762452] 
85. Coleman RJ, Beharry KD, Brock RS, Abad-Santos P, Abad-Santos M, Modanlou HD. Effects of brief, clustered versus dispersed hypoxic episodes on systemic and ocular growth factors in a rat model of oxygen-induced retinopathy. Pediatr Res. 2008; 64:50-5. [PubMed: 18344903]

86. Can E, Bülbül A, Uslu S, Cömert S, Bolat F, Nuhoğlu A. Effects of aggressive parenteral nutrition on growth and clinical outcome in preterm infants. Pediatr Int. 2012; 54:869-74. [PubMed: 22882288]

87. Hansen-Pupp I, Löfqvist C, Polberger S, et al. Influence of insulin-like growth factor I and nutrition during phases of postnatal growth in very preterm infants. Pediatr Res. 2011; 69(5 Pt 1): 448-53. [PubMed: 21263374]

88. Kaempf JW, Kaempf AJ, Wu Y, Stawarz M, Niemeyer J, Grunkemeier G. Hyperglycemia, insulin and slower growth velocity may increase the risk of retinopathy of prematurity. J Perinatol. 2011; 31:251-7. [PubMed: 21233796]

89. Garg R, Agthe AG, Donohue PK, Lehmann CU. Hyperglycemia and retinopathy of prematurity in very low birth weight infants. J Perinatol. 2003; 23:186-94. [PubMed: 12732854]

90. Ertl T, Gyarmati J, Gaal V, Szabo I. Relationship between hyperglycemia and retinopathy of prematurity in very low birth weight infants. Biol Neonate. 2006; 89:56-9. [PubMed: 16155387]

91. Blanco CL, Baillargeon JG, Morrison RL, Gong AK. Hyperglycemia in extremely low birth weight infants in a predominantly Hispanic population and related morbidities. J Perinatol. 2006; 26:737-41. [PubMed: 16929343]

92. Ley D, Hansen-Pupp I, Niklasson A, et al. Longitudinal infusion of a complex of insulin-like growth factor-I and IGF-binding protein-3 in five preterm infants: pharmacokinetics and shortterm safety. Pediatr Res. 2013; 73:68-74. [PubMed: 23095978] 


\section{Practice points}

- Loss of maternal-fetal interaction after preterm birth results in loss of nutrients and growth factors, e.g. IGF-1 and $\omega-3$ polyunsaturated fatty acids.

- Poor postnatal growth is associated with abnormal retinal blood vessel development and ROP.

- Factors contributing to poor postnatal growth in very preterm infants:

- increased frequency of intrauterine growth restriction

- increased metabolic rate

- insufficient nutrition

- low serum IGF-1 concentrations

- oxygen treatment

- morbidities. 


\section{Research directions}

- Conditions after preterm birth differ from intrauterine conditions. Research must focus on how to prevent ROP and other morbidity by optimizing treatment of infants spending the third trimester extrauterine by providing appropriate levels of:

- essential nutrients and energy

- hormones, growth factors and other hitherto unknown factors important for growth and development

- oxygen supplementation

- treatment of inflammation/infection. 


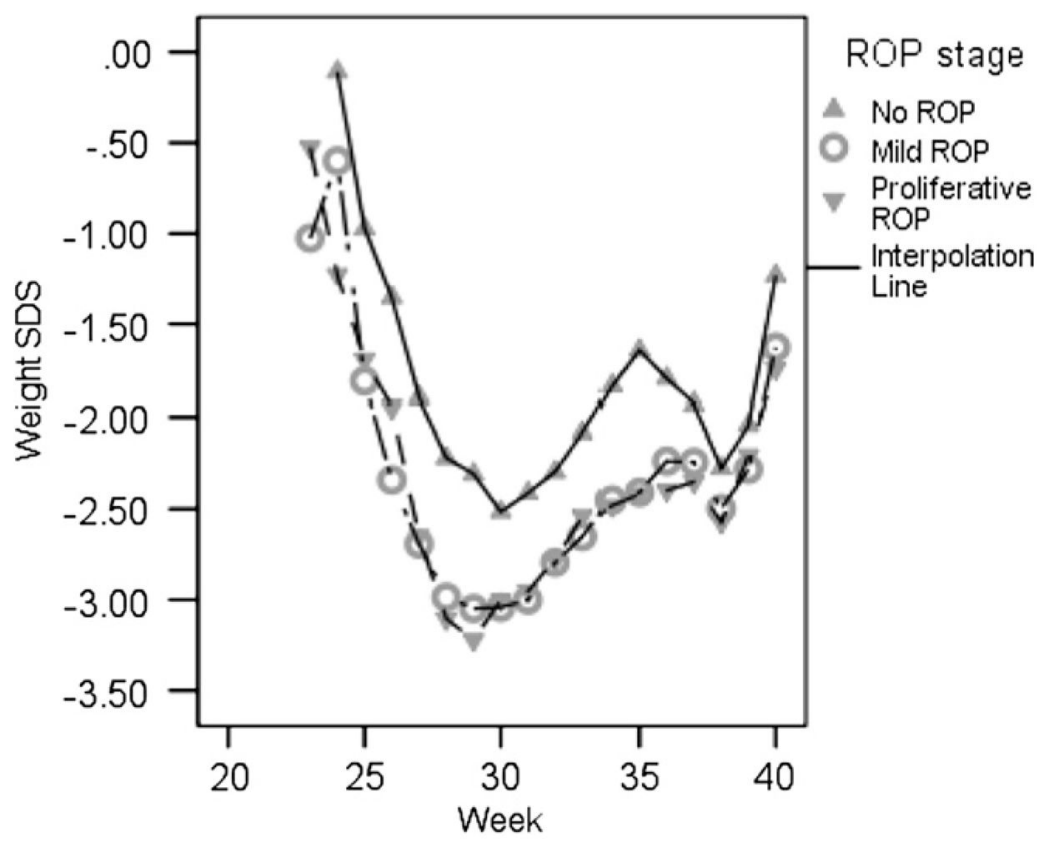

Fig. 1.

Longitudinal development of weight standard deviation scores (SDS) in relation to postmenstrual age (weeks) in infants with different retinopathy of prematurity (ROP) stages $(n=136) .{ }^{41,42}$ 


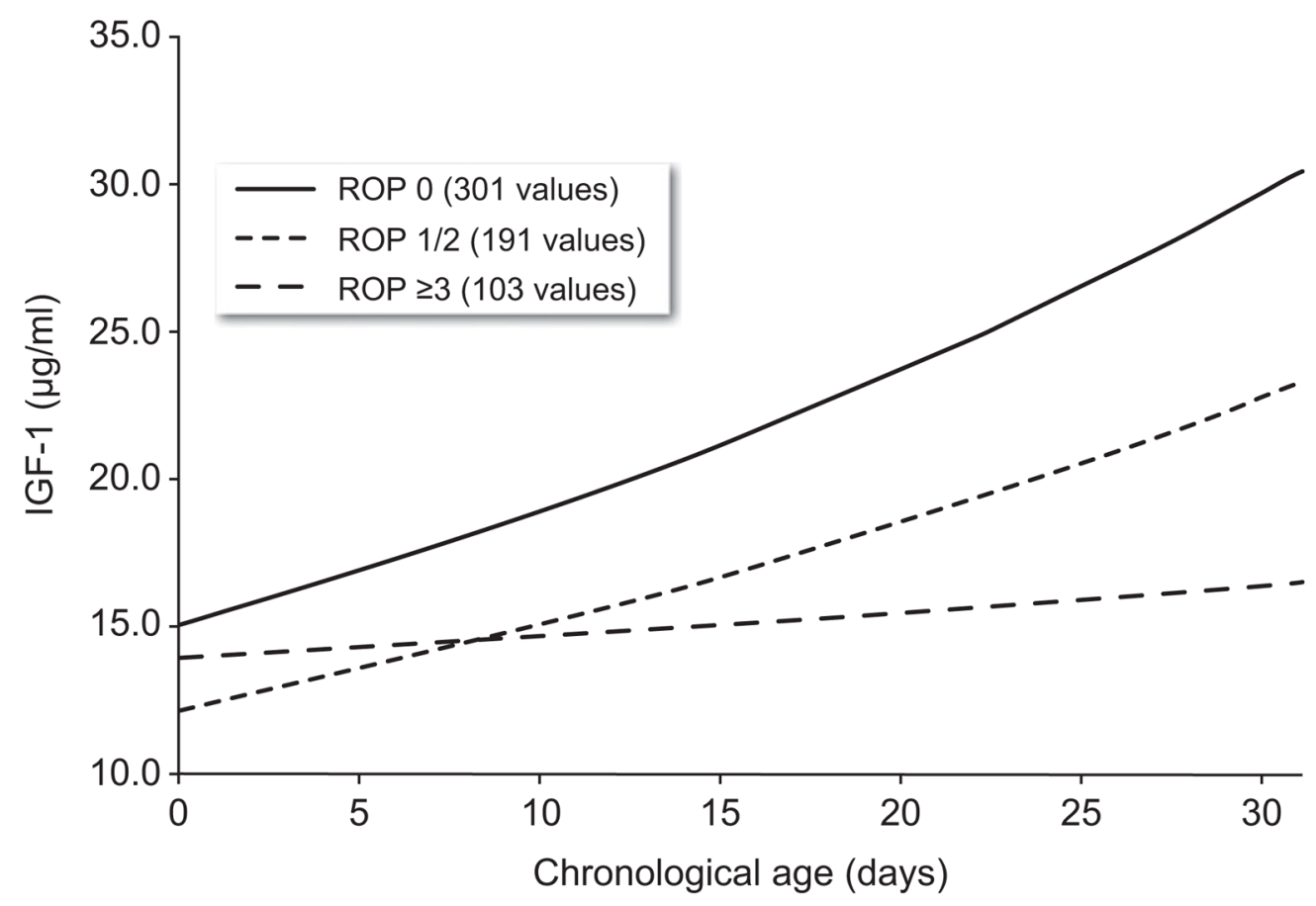

Fig. 2.

Longitudinal development of serum insulin-like growth factor-1 (IGF-1) in relation to chronologic age in infants with different retinopathy of prematurity (ROP) stages $(n=$ 136). ${ }^{41,42}$ high risk infants. Alarms usually occur during the first month after birth whereas proliferative ROP develops weeks to months later. This suggests that interventions to improve growth in the early neonatal period might help prevent ROP. 


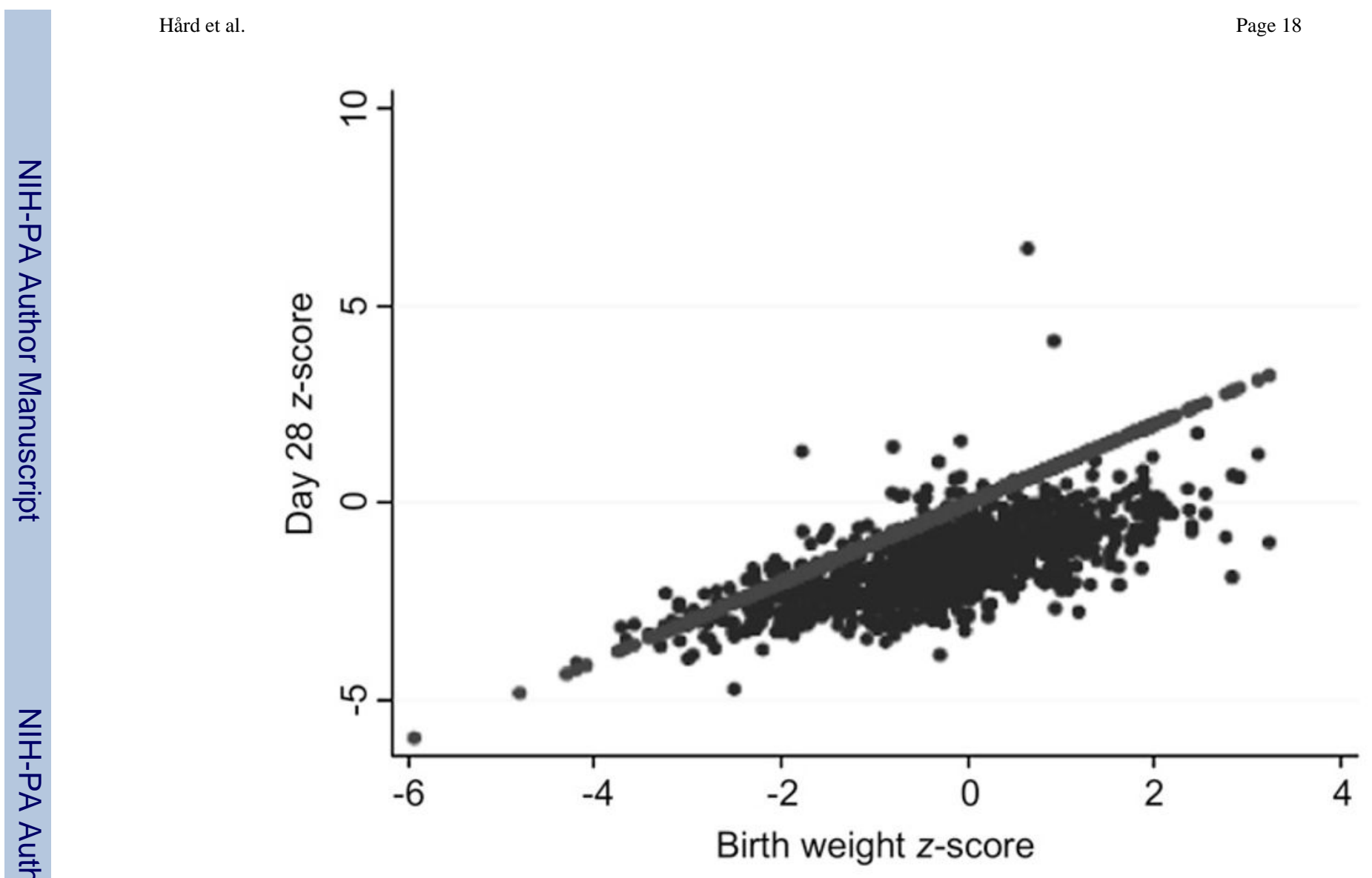

Fig. 3.

Scatterplot of $z$-scores at birth ( $x$-axis) and at 28 days ( $y$-axis). ${ }^{49}$ 


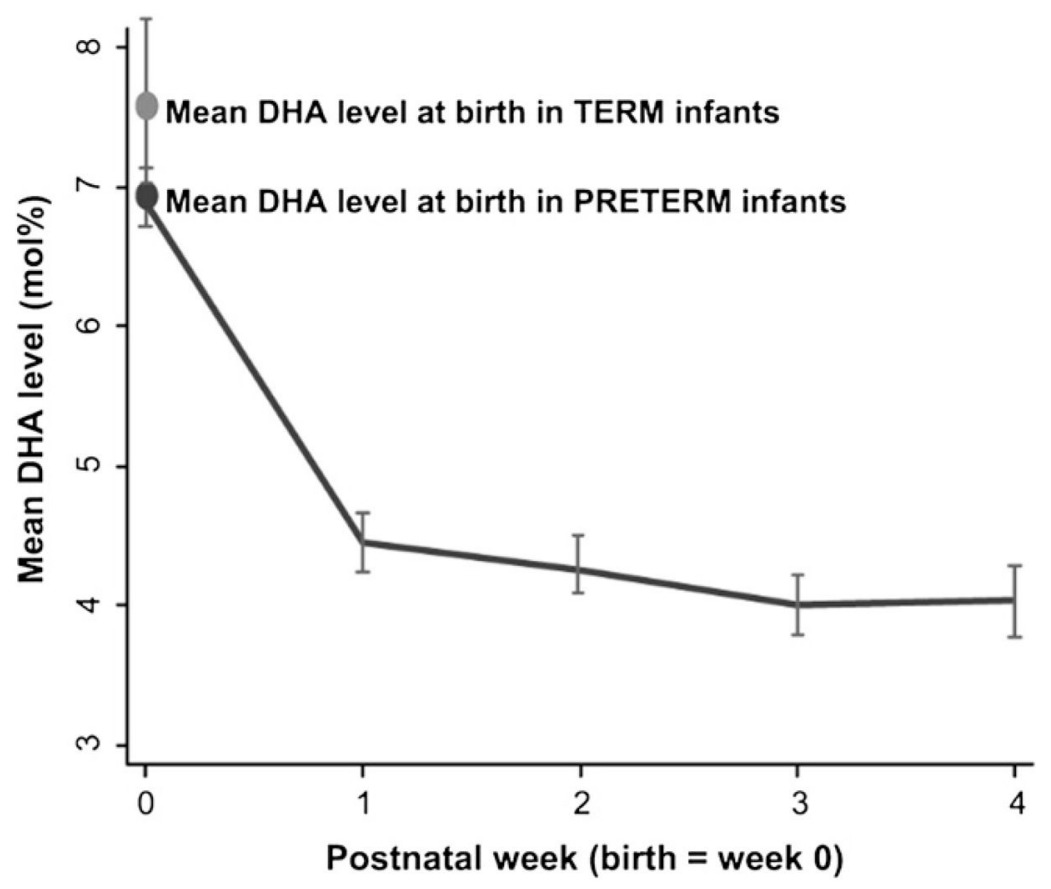

Fig. 4.

Docosahexaenoic acid (DHA) levels in preterm infants decrease soon after birth and plateau by the first postnatal week. ${ }^{62}$ 